\title{
The expression of SOCS1 and TLR4-NFKB pathway molecules in neoplastic cells as potential biomarker for the aggressive tumor phenotype in laryngeal carcinoma
}

\author{
Katarzyna Starska ${ }^{1}$, Ewa Forma ${ }^{2}$, Iwona Lewy-Trenda ${ }^{3}$, Olga Stasikowska 3 , \\ Magdalena Bryś2, Wanda M. Krajewska ${ }^{2}$ and Marek Lukomski ${ }^{1}$
}

\author{
${ }^{1}$ Department of Laryngological Oncology, Medical University of Lodz, Kopcinskiego 22, \\ 90-153 Lodz, Poland \\ ${ }^{2}$ Department of Cytobiochemistry, University of Lodz, Banacha 12/16, 90-237 Lodz, Poland \\ ${ }^{3}$ Department of Pathology, Medical University of Lodz, Pomorska 251, 92-213 Lodz, Poland
}

\begin{abstract}
Suppressor of cytokine signaling 1 (SOCS1) is the key regulator of cytokine-mediated innate and adaptive immunity. One of the molecular mechanisms of SOCS1 is connected with inhibition of TLR4-NFKB pathway. The relationships among these molecules in laryngeal carcinoma are not exactly known. In this preliminary study we focused on their special activity and role in regulation of development and progression of laryngeal carcinoma. To investigate NFKB (p65 subunit) nuclear and cytoplasmic expression in 45 tumor samples of advanced laryngeal carcinoma IHC staining was performed. To determine the mRNA expression levels of TLR4, IRAK1, TRAF6 and SOCS1 in isolated neoplasm cells and non-cancerous adjacent mucosa epithelial cells RT-PCR was used. The invasiveness of laryngeal carcinomas was evaluated according to tumor front grading, TFG, which included tumor-related features (cytoplasmic differentiation, nuclear polymorphism, number of mitoses) and adjacent stroma-related characteristics of the peripheral edge of tumor infiltration (mode of infiltration, depth of invasion and plasmalymphocytic infiltration). The relationships between $\mathrm{pT}, \mathrm{pN}$ status, the histological $\mathrm{G}$ grade, certain clinicopathological characteristics as well as postoperative observation time and the mRNA expression of the molecules mentioned earlier were investigated. Significant differences of TLR4-NFKB pathway molecules and SOCS1 mRNA expression in laryngeal tumor cells and normal adjacent mucosa cells as well as significant interconnections of TLR4, SOCS1 and $\mathrm{NFKB}(\mathrm{p} 65)$ in isolated tumor cells were obtained. This preliminary study demonstrated that the expression of SOCS1 and TLR4-NFKB pathway molecules had a strong association with the aggressiveness of laryngeal carcinoma. Positive relationships of TRAF6 in tumor margin cells with the histological grade and the mode of tumor invasion as well as the TFG total score were highlighted. Significant positive correlations were found between the TLR4 in tumor central cells and the TFG total score. Negative relationships of SOCS1 in tumor central cells with the histological grade were also noted. Significant positive correlations were found between the cytoplasmic $\mathrm{NFKB}(\mathrm{p} 65)$ and the mode of invasion as well as TFG total score. Our findings confirmed the importance of SOCS1 and TLR4-NFKB pathway molecules as potential biomarkers for assessment of the aggressive tumor phenotype in laryngeal carcinoma.
\end{abstract}

Key words: laryngeal carcinoma, SOCS1 (suppressor of cytokine signaling 1), TLR4 (toll-like receptor 4), IRAK1 (interleukin -1 receptor - associated kinase), TRAF6 (TNF receptor-associated factor 6), NFKB (nuclear factor kappa B, p65 subunit), TFG (tumor front grading)

\section{Introduction}

Suppressor of cytokine signaling/cytokine-inducible $\mathrm{SH} 2$ protein (SOCS/CIS) is a family of eight intracellular proteins (SOCS 1-7, CIS) that regulate the

Correspondence: K. Starska, Department of Otolaryngology and Laryngological Oncology, Medical University of Lodz, Kopcinskiego 22, 90-153 Lodz, Poland,

tel./fax. 4842 6785785, email: katarzyna.starska@op.pl responses of immune cells to cytokines [1-6]. One of the best characterized SOCS/CIS family members, which play the pivotal role in many immunological and pathological processes, is SOCS1 [1-8]. In vivo and in vitro data introduce the role of SOCS1 protein as tumor suppressor [9-11]. The molecular mechanisms in various types of malignances by which SOCS1 negatively regulate activation of innate and adaptive immunity are connected with inhibition of the JAKs/STAT1 (Janus family kinases/signal transducer 
and activator of transcription-1) pathway [1,3-5]. SOCS1 can inhibit JAK tyrosine kinase activity by the kinase inhibitory region (KIR) in N-terminal domain which act as pseudosubstrat. SOCS1 binds directly to the JAK through its $\mathrm{SH} 2$ domain thus inhibits catalytic activity [1]. On the other hand, a direct effect of SOCS1 on the toll-like receptor (TLR)/MD2 complex, NFKB and c-Jun N-terminal kinases (JNK)/p38 pathway in various types of hematopoietic cells including $\mathrm{T}$ and NK T cells as well as antigen-presenting cells including macrophages and dendritic cells has been also considered $[1,4,6,12]$. Induced proteasomal degradation of p65 subunit of NF-KB is a potential mechanism of TLRs signal suppression by SOCS proteins family [7,8]. Upon TLRs stimulation MyD88 adaptor molecules are recruited to the receptor complex via the TIR domain and signaling molecules, among which are interleukin- 1 receptor - associated kinase (IRAK1), TNF receptor-associated factor 6 (TRAF6) and mitogen-activated protein kinase (MAPK), activate NFKB $[1,4,7,8,12]$. However, little is known about the interconnections between SOCS1 and TLRs-NFKB signal pathway in neoplastic cells of laryngeal carcinoma, the association with clinicopathological characteristics and the role in determining primary tumor's behavior.

The aim of this preliminary study was to evaluate the potential significance of SOCS1 and TLR4-NFKB pathway molecules expression as potential biomarkers for the aggressive tumor phenotype in laryngeal carcinoma.

\section{Material and methods}

Tissue samples, histological classification and morphological features. For this preliminary study, archival paraffin-embedded tissue samples from 24 patients (22 men, 2 women; age 47-81 yrs; mean age $56 \pm 8$ yrs) surgically treated for advanced laryngeal squamous cell carcinoma (pT3 and pT4) were utilized. The criteria for patient participation in this study were as follows: 1 . histologically confirmed diagnosis of carcinoma planoepitheliale, 2. primary surgical resection of the larynx without receiving prior immuno-, radioor chemotherapy, 3. absence of distant metastases. All specimens were confirmed by routine clinical diagnosis according to the UICC TNM classification of 2003 for head and neck carcinomas [13]. Clinicomorphological characteristics of patients were listed in Table 1. Morphological estimation was performed on H\&E-stained sections in the most invasive of the tumor, according to TFG classification [14]. TFG features in the peripheral zones of the tumor were assessed in at least five different regions of the peripheral part of the tumor (magnification $\times 200$, number of mitoses magnification $\times 400$ ). Each factor was graded according to a scale ranging from 1 to 4 . The total morphological TFG score was computed as the sum of six parameters, with a maximum score of 24 points. According to the TFG total score, tumors were divided into 5 groups: 6-9, 10-13, 14$17,18-21$ and $>22$ TFG points. Certain characteristics of tumor front grading, TFG, are shown in Table 2. Postoperative time of observation was 1 to 42 months; mean $14.1 \pm 13.9$ months.

Non-cancerous/cancerous epithelium cells isolation. After radical laryngectomy, the surgical tissue specimens were excised aseptically immediately after operation from the least four tumor sites: two from tumor centre, two from tumor margin and two sites of
Table 1. Clinical characteristics of group studied

\begin{tabular}{|c|c|}
\hline licature & Number of patients (\%) \\
\hline \multicolumn{2}{|c|}{ Sex } \\
\hline $\begin{array}{l}\text { men } \\
\text { women }\end{array}$ & $\begin{array}{c}22(91.7) \\
2(8.3)\end{array}$ \\
\hline \multicolumn{2}{|c|}{ Surgical treatment } \\
\hline $\begin{array}{l}\text { lotal laryngectomy } \\
\text { neck dissection } \\
\text { selective neck dissection (SND) } \\
\text { radical neck dissection (RND) }\end{array}$ & $\begin{array}{l}24(100.0) \\
22(91.7) \\
20(83.3) \\
2(8.3)\end{array}$ \\
\hline \multicolumn{2}{|l|}{$\mathrm{pl}$} \\
\hline $\begin{array}{l}\text { pT3 } \\
\text { pT4 }\end{array}$ & $\begin{array}{l}10(41.7) \\
14(58.3)\end{array}$ \\
\hline \multicolumn{2}{|l|}{$\mathrm{pN}$} \\
\hline $\begin{array}{l}\mathrm{pN} 0 \\
\mathrm{pN} 1-3 \\
\mathrm{pN} 1 \\
\mathrm{pN} 2 \\
\mathrm{pN} 3\end{array}$ & $\begin{array}{c}9(37.5) \\
15(62.5) \\
6(25.0) \\
4(16.6) \\
5(20.9)\end{array}$ \\
\hline \multicolumn{2}{|c|}{ Histological differentiation } \\
\hline $\begin{array}{l}\text { G1 } \\
\mathrm{G} 2 \\
\mathrm{G} 3\end{array}$ & $\begin{array}{c}2(8.3) \\
13(54.2) \\
9(37.5)\end{array}$ \\
\hline \multicolumn{2}{|c|}{ TFG score } \\
\hline $\begin{array}{l}6-9 \text { points } \\
10-13 \text { points } \\
14-17 \text { points } \\
18-21 \text { points } \\
>22 \text { points }\end{array}$ & $\begin{array}{c}0 \\
2(9.1) \\
16(65.9) \\
6(25.0) \\
0\end{array}$ \\
\hline
\end{tabular}

non-cancerous adjacent laryngeal epithelium. Fragments of tissues were washed with PBS for removal of contaminated blood and next inserted in RPMI 1640 medium (Biomed, Poland) supplemented with antibiotics streptomycin/ penicillin/ gentamycin 1\% v/v (Sigma, Aldrich, Germany). The whole procedure was performed on an ice plateau. Briefly, tissue specimens were cut with surgical knife, minced with a scalpel. This was done in RPMI 1640 medium (Biomed, Poland) supplemented with antibiotics streptomycin/ penicillin/ gentamycin 2\%v/v (Sigma, Aldrich, Germany). Fragments of tissues were then washed three times with Hanks solution (Biomed Lublin, Poland). Next the tumor and normal epithelial pieces were digested overnight (for 18h) in Nunc Petridishes with $0.16 \mathrm{mg} / \mathrm{mL}$ hyaluronidase (Sigma, Aldrich, Germany), $0.55 \mathrm{mg} / \mathrm{mL}$ collagenase (Sigma, Aldrich, Germany) in the presence of the antibiotics streptomycin/penicillin/gentamycin $1 \% \mathrm{v} / \mathrm{v}$ (Sigma, Aldrich, Germany) in a $37^{\circ} \mathrm{C}, 5 \% \mathrm{CO}_{2}$ (Cellstar Incubator). The digested tissues were pressed gently through a $50-\mu \mathrm{m}$ (mesh) sieve (Sigma, Aldrich, Germany) with RPMI 1640 medium (Biomed, Poland). Subsequently, the suspension was three times washed with PBS (without $\mathrm{Mg}^{2+}$ and $\mathrm{Ca}^{2+}$ ) for $20 \mathrm{~min}$ in a $8^{\circ} \mathrm{C}$ by centrifugation in MPW-350R centrifuge at $1800 \mathrm{rpm} / 500 \mathrm{rcf}$ and poured over by dyspase solution $2.4 \mathrm{U} / \mathrm{mL}$, incubated for $30 \mathrm{~min}$ in a $37^{\circ} \mathrm{C}$ and next resuspended in $1 \mathrm{~mL}$ PBS. The concentration of cells was estimated using a microscope and Bürker's chamber. To get rid of the apoptotic and necrotic cells the columns of Magnetic Cell Sorting Separator MACS (Miltenyi Biotec, Germany) and Dead Cell Removal Kit was used. The recovered cells were checked (typical epithelial morphology, immunohistochemical positive reactions with policlonal antibodies [NCL-C11, Multi-Cytokeratin 
Table 2. Features used for tumor front grading and numeric score [14]

\begin{tabular}{|c|c|c|c|c|}
\hline \multirow{2}{*}{ Features } & \multicolumn{4}{|c|}{ Score points } \\
\hline & 1 & 2 & 3 & 4 \\
\hline Cytoplasmic differentiation & $\begin{array}{c}\text { high } \\
(>50 \% \text { keratinized) }\end{array}$ & $\begin{array}{c}\text { moderate } \\
(20-50 \% \text { keratinized })\end{array}$ & $\begin{array}{c}\text { poor } \\
(5-20 \% \text { keratinized })\end{array}$ & $\begin{array}{c}\text { none } \\
(<5 \% \text { keratinized })\end{array}$ \\
\hline $\begin{array}{l}\text { Nuclear diffcrentiation } \\
\text { (polymorphism) }\end{array}$ & $\begin{array}{c}\text { high } \\
\text { (>75\% mature cells) }\end{array}$ & $\begin{array}{c}\text { modcratc } \\
\text { (50-75\% mature cells) }\end{array}$ & $\begin{array}{c}\text { poor } \\
(25-50 \% \text { mature cells })\end{array}$ & $\begin{array}{c}\text { nonc } \\
(<25 \% \text { mature cells })\end{array}$ \\
\hline Number of mitoses & $\begin{array}{l}\text { single } \\
(0-1)\end{array}$ & $\begin{array}{l}\text { moderate number } \\
\qquad(2-3)\end{array}$ & $\begin{array}{l}\text { large number } \\
\qquad(4-5)\end{array}$ & $\begin{array}{l}\text { very numerous } \\
\qquad(>5)\end{array}$ \\
\hline Mode of invasion & $\begin{array}{l}\text { well-delined } \\
\text { borderline }\end{array}$ & $\begin{array}{l}\text { cords; less marked } \\
\text { borderline }\end{array}$ & $\begin{array}{l}\text { groups of cells; } \\
\text { no distinct borderline }\end{array}$ & diffuse growth \\
\hline Stage of invasion (depth) & possible invasion & $\begin{array}{l}\text { microinvasion } \\
\text { ( } \mathrm{c} \mathrm{cw} \text { cords) }\end{array}$ & $\begin{array}{l}\text { nodular } \\
\text { into submucosa }\end{array}$ & $\begin{array}{l}\text { invasion deeper than } \\
\text { submucosa }\end{array}$ \\
\hline $\begin{array}{l}\text { Plasmalymphocytic } \\
\text { invasion }\end{array}$ & $\begin{array}{c}\text { marked } \\
\text { (continuous rim) }\end{array}$ & $\begin{array}{c}\text { moderate } \\
\text { (many large patches) }\end{array}$ & $\begin{array}{c}\text { slight } \\
\text { (few stmall patches) }\end{array}$ & none \\
\hline
\end{tabular}

4/5/6/8/10/13/18, RTU-D Novostatin Universal Detection Kit, NCL-L-DAB Liquid DAB Substrate Kit; Novocastra UK]) and counted for viability with trypan blue staining method. The isolated laryngeal epithelial cells (TCC - tumor central cells, TMC - tumor marginal cells, NCC - non-cancerous epithelial cells) were collected immediately after procedure and RNAlater RNA Stabilization Reagent (QIAGEN GmbH, Hilden, Germany) was added to the cell pellets. Cell pellets were stored at $-80^{\circ} \mathrm{C}$ until isolation RNA.

RNA extraction and reverse transcription PCR (RT-PCR) analysis. Total RNA was isolated using TRI Reagent (SigmaAldrich Co., USA) and quantified by spectrophotometry at 260 nm. RNA with a $260 / 280 \mathrm{~nm}$ ratio in the range $1.8-2.0$ was considered high quality. RT-PCR was performed using a RNA PCR Kit ver. 3.0 (Takara Shuzo Co., Ltd, Japan) according to the manufacturer's instructions. The TLR4, IRAK1, TRAF6, SOCS1 gene and $\beta$-actin gene as standard were amplified using the specific primers: TLR4(f) 5'-CTGCAATGGATCAAGGACCA-3', TLR4(r)

5'-TCCCACTCCAGGTAAGTGTT-3', IRAK1(f)

5'-GACCAAGTATCTGAAAGACCTGGTG-3', IRAK1(r)

5'-TCAGCTCTGAAATTCATCACTTTC-3', TRAF6(f)

5'-TGATAGTGTGGGTGGAACTG-3', TRAF6(r)

5'-CTCCTTGGACAATCCTTCAG-3', SOCS1(f)

5'-ACCTTCTTGGTGCGCGAC-3', SOCS1(r)

5'-AAGCCATCTTCACGCTGAGC-3', $\beta$-actin(f)

5'-CGTGACATTAAGGAGAAGCTGTGC-3', $\beta$-actin(r)

5'-CTCAGGAGGAGCAATGATCTTGAT-3'.

The thermal cycling parameters were 30 rounds of $1 \mathrm{~min}$ at $94^{\circ} \mathrm{C}$, $1 \mathrm{~min}$ at $51^{\circ} \mathrm{C}$ (TLR4, IRAK1, TRAF6, SOCS1, $\beta$-actin), and 3 min at $72^{\circ} \mathrm{C}$ using a GeneAmp PCR System 9700 (Perkin-Elmer Co, Shelton, USA). The size of amplified fragments was 622,847 , 445,387 and 374 bp for TLR4, IRAK1, TRAF6, SOCS1 and $\beta-$ actin, respectively. After amplification $10 \mu \mathrm{L}$ of PCR products were combined with $1 \mu \mathrm{L}$ of gel loading buffer and the mixture was electrophoresed on $8 \%$ polyacrylamide gel (acrylamide/bisacrylamide (30/2), 10\% ammonium peroxydisulfate, $0.075 \%$ tetramethyl ethylenediamine, at $80 \mathrm{~V}$ for $3 \mathrm{hrs}$ in Trisborate, EDTA, pH 8.0 (TBE) buffer. The gel was silver stained. To exclude contamination of genomic DNA as a source for amplified products, each reaction was also carried out without reverse transcriptase. In addition, no template control was run for both the RT and PCR stages for each of the primer sets and none showed any visible PCR products. For qualitative and quantitative analysis of silver nitrate stained gels the software program Gel-Pro ${ }^{\circledR}$ Analyzer 3.0 (Media Cybernetics, USA) was used. All RT-PCR reactions were repeated 3 times for each sample. The integrated optical den- sity (IOD) of the bands in a digitized picture was measured. TLR4 and IRAK1, TRAF6, SOCS1 gene expression was determined as the ratio of TLR4, IRAK1, TRAF6 and SOCS1 to $\beta$-actin.

Immunohistochemistry (IHC). Paraffin sections were mounted onto SuperFrost slides, deparaffinized, then treated in a microwave oven in a solution of citrate buffer, $\mathrm{pH} 6.0$ for 30 minutes $(2 \times 5 \mathrm{~min}$ utes $360 \mathrm{~W}, 4 \times 5$ minutes $180 \mathrm{~W}$ ) and transferred to distilled water. Endogenous peroxidase activity was blocked by $0,3 \%$ hydrogen peroxide in distilled water for 30 minutes, and then sections were rinsed with Tris-buffered saline (TBS, DakoCytomation, Denmark) and incubated with monoclonal rabbit anti-human NFKB (p65 subunit) antibody (IBL Co., LTD, Japan), dilution: 1:100. Afterwards EnVision+Systems-HRP for mouse and rabbit (DakoCytomation, Denmark) prepared according to the instructions of the manufacturer were used. Visualisation was performed by incubating the sections in a solution of 3,3'-diaminobenzidine (DakoCytomation, Denmark). After washing, the sections were counter-stained with hematoxylin and coverslipped. For each antibody and for each sample a negative control were processed. Negative controls were carried out by incubation in the absence of the primary antibody and always yielded negative results. Positive tissue control was used to indicate correctly prepared tissues and staining techniques. Positive tissue control was skin. One positive tissue control was included for each set of test conditions in each staining run. $\mathrm{NF \kappa B}(\mathrm{p} 65$ subunit) protein was detected in the cell cytoplasm and/or in the nucleus. The intensity of IHC staining (in at least five different regions) as a percentage of tumor cells with $\mathrm{NFKB}(\mathrm{p} 65)$ cytoplasmic expression was scored using three-tier system (ranks): 0 - none; 1 - weak to intermediate $(<50 \%$ cells with positive staining); 2 - strong ( $\geq 50 \%$ positive cells). The nuclear staining intensity was classified (ranks) as: 0 - negative; 1 - positive (cells with positive staining). At least 10 high-power fields (magn. 40x) were assessed for each specimen. All slides were assessed in three independent sessions by two researchers.

Ethical issues. The study was performed with the approval of the Bioethical Commission of the Medical University of Lodz and the National Science Council, Poland (No RNN/15/03/KN).

Statistical analysis of data. The statistical calculations were made by STATISTICA 5.0 (StatSoft, Inc. USA). None of the parameters recorded in tumor material passed tests for being normally distributed (Kolmogorov-Smirnow test) and therefore nonparametric statistical tests were used for analyzing the results (Spearman's rank analysis; Mann-Whitney U test). P-values $<0.05$ were considered to be significant. 
Table 3. Mean expression of TLR4, IRAK1, TRAF6 and SOCS1 in various types of laryngeal epithelial cells

\begin{tabular}{|c|c|c|c|c|}
\hline $\begin{array}{l}\text { Type of epithelial } \\
\text { laryngeal cell }\end{array}$ & 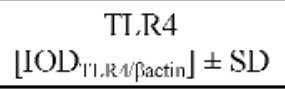 & $\begin{array}{c}\mathrm{IR} \wedge \mathrm{K} 1 \\
\left.\left.\lfloor\mathrm{IOD})_{\mathbb{I R A K} 1 / \text { (actin }}\right\rfloor \pm \mathrm{SD}\right)\end{array}$ & 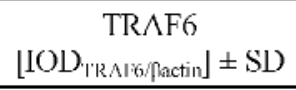 & 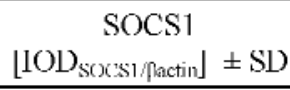 \\
\hline TMC & $0.26 \pm 0.05$ & $0.33 \pm 0.10$ & $0.40 \pm 0.07$ & $0.50 \pm 0.14$ \\
\hline $\mathrm{TCC}$ & $0.29 \pm 0.07$ & $0.41 \pm 0.10$ & $0.35 \pm 0.07$ & $0.51 \pm 0.10$ \\
\hline $\mathrm{NNC}$ & $0.22 \pm 0.03$ & $0.32 \pm 0.15$ & $0.29 \pm 0.08$ & $0.36 \pm 0.14$ \\
\hline
\end{tabular}

TMC - tumor border cells; TCC - tumor central cells; NNC - normal adjacent mucosa cells

\section{Results}

\section{TLR4, IRAK1, TRAF6 and SOCS1 gene expression in laryngeal epithelial cells. Immunoexpression of cytoplasmic and nuclear $N F K B(p 65)$ in laryngeal carcinoma specimens. The relationships between $T L R 4-N F K B$ pathway molecules expression as well as SOCS1 expression and $N F \kappa B(p 65)$ immunostaining}

Our results demonstrated that laryngeal cancerous epithelial cells as well as non-cancerous adjacent mucosa epithelial cells, used as a control, expressed mRNA for TLR4, IRAK1, TRAF6 and SOCS1. To investigate the differences between the expression of TLR4, IRAK1, TRAF6 and SOCS1 in the various types of epithelial cells, the RT-PCR results for a chosen pair of epithelial cells were juxtaposed. The mean mRNA content of studied molecules in epithelial neoplastic cells and in normal adjacent mucosa epithelial cells is introduced in Table 3. We observed significant differences in TRAF6 expression between non-cancerous epithelial cells (NCC) and tumor marginal cells (TMC) $(\mathrm{p}=0.02)$. Moreover, we noted significant differences in TLR4, IRAK1 mRNA content between non-cancerous epithelial cells (NCC) and tumor central cells (TCC) ( $p=0.002$ and $p=0.04$, respectively). Furthermore, we found significant differences between SOCS1 expression in NCC and TMC ( $p=0.01)$ as well as in TCC of the carcinoma infiltration $(p=0.001)$. Representative expression of TLR4, IRAK1, TRAF6 and SOCS1 in TMC, TCC and NCC is shown in Figure 1.

In the present study, we recorded cytoplasmic and nuclear data of NFKB(p65) immunostaining separately, taking into consideration the apparent biologic importance of NFKB localization. We noticed a trend towards $\mathrm{NF \kappa B}(\mathrm{p} 65)$ the excessive cytoplasmic reserve, along with infrequent translocation into nucleus. Our experiments confirmed the cytoplasmic NFKB(p65) (NFKB-c) positive expression in $95.8 \%(23 / 24)$ of all tumor samples $-54.2 \%(13 / 24)$ cases had weak to intermediate positive IHC staining (with IHC index of $<50 \%$ ) and $41.6 \%(10 / 24)$ cases had strong IHC positive staining (with IHC index of $\geq 50 \%$ ). The nuclear NFkB(p65) (NFkB-n) positive expression in 33.3\% (8/24) and neg- ative IHC staining for NFKB-n in $66.7 \%$ (16/24) cases of squamous cell laryngeal carcinoma were observed. Representative IHC stainings for NFKB-c and NFKB-n are shown in Figs. 2AB. To verify whether TLR4 expression, the first signal in TLR4-NFKB pathway, as well as SOCS1 expression, a negative regulator of this cascade, can determine NFKB(p65) expression in cytoplasm and nucleus of squamous cell laryngeal carcinoma cells or not, we juxtaposed the level of mRNA for these molecules with $\mathrm{NFKB}(\mathrm{p} 65)$ immunoexpression. Our results indicated a significant dependence of both NFKB-c $(r=0.54, p=0.04)$ and NFKB-n $(r=0.55, p=0.03)$ on TLR4 expression in border cancerous cells from the most invasiveness part of the neoplastic infiltration. The tumors with a high TLR4 expression had more intensive $\mathrm{NF \kappa B}(\mathrm{p} 65)$ immunoexpression in either cytoplasm or nucleus of the neoplastic cells. Our study did not revealed any other interconnections of $\mathrm{NFKB}(\mathrm{p} 65)$ with TLRs-NFKB pathway molecules mRNA content. For neither NFKB-c and NFKB-n nor SOCS1 there was a statistically significant association between IHC stain-

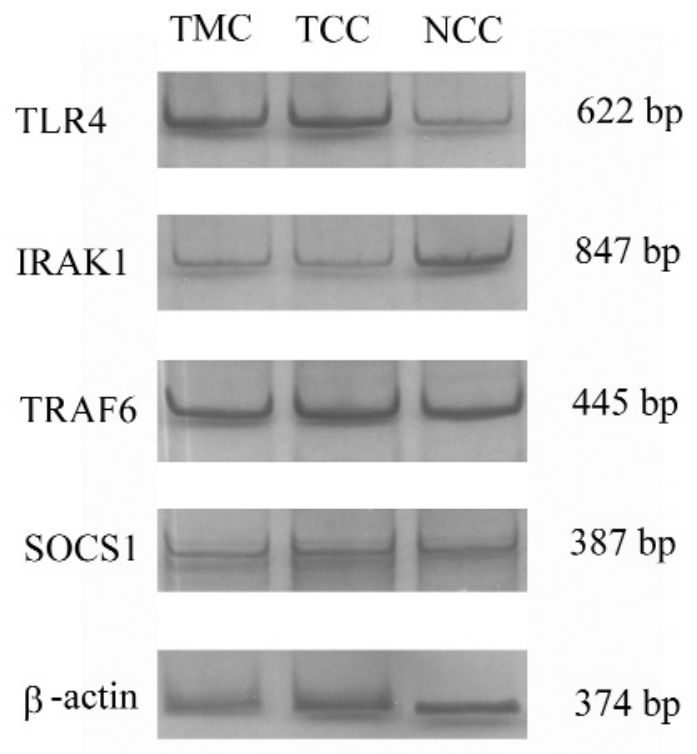

Fig. 1. Representative TLR4, IRAK1, TRAF6 and SOCS1 mRNA expression in tumor border epithelial cells (TMC), tumor central epithelial cells (TCC) and normal adjacent mucosa epithelial cells (NCC) of squamous cell laryngeal carcinoma. 


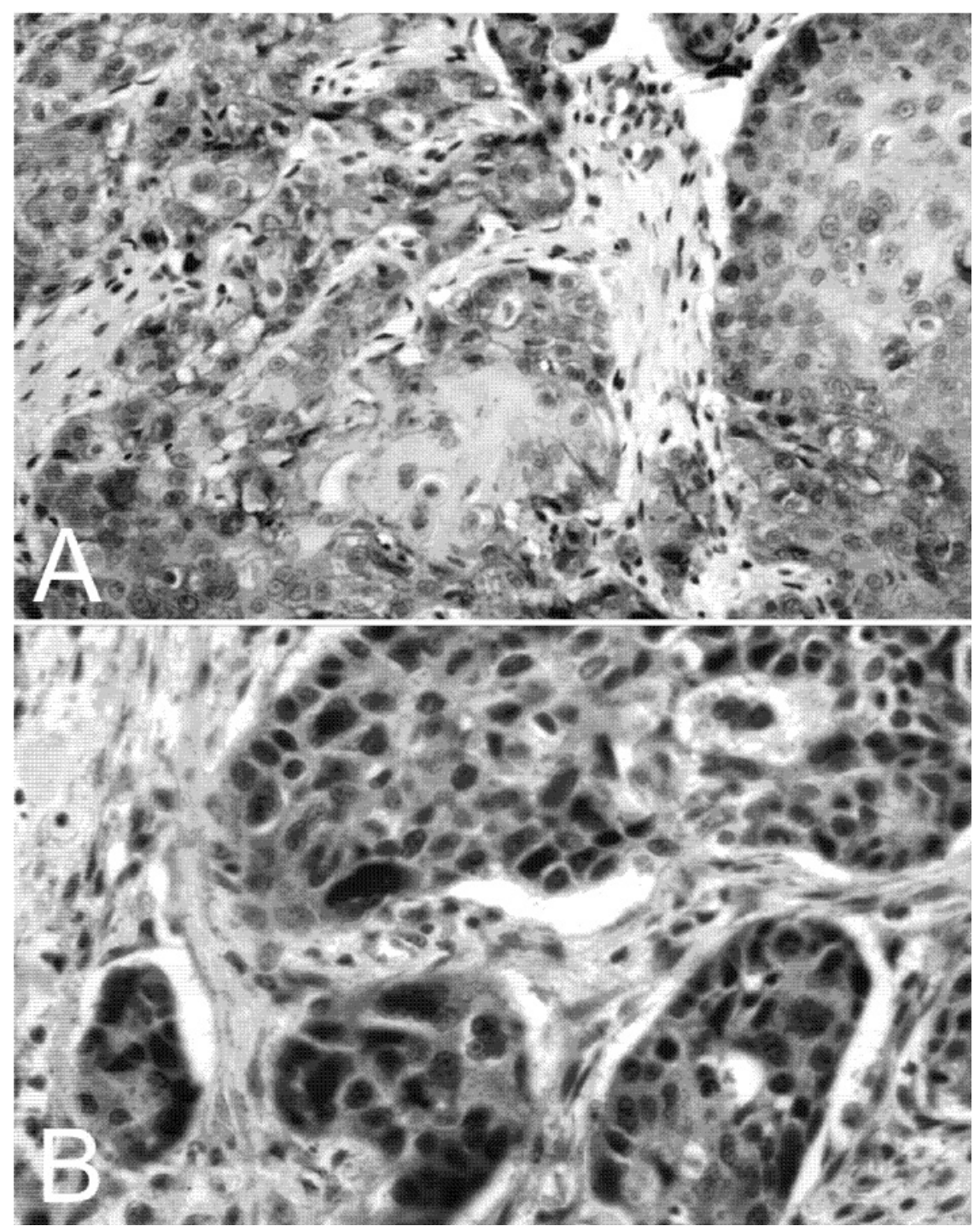

Fig. 2. Representative immunohistochemical staining (IHC) for cytoplasmic NFKB (NFKB-c) and nuclear NFKB (NFKB-n) in laryngeal carcinoma tissues. (A) IHC for NFKB-c with index of $\geq 50 \%$ (characterized by dark grey cytoplasm of tumor cells). Original magnification, $\times 200$. (B) Positive IHC staining for NFKB-n (characterized by black nuclei of tumor cells). Original magnification, $\times 300$. ing and mRNA expression level, in both TMC and TCC. However, we observed tends to increase of NFKB immunoexpression in tumors with a lower SOCS1 expression but these association did not reached a statistical significant level $(\mathrm{r}=-0.38$ for relationship between NFKB-c and SOCS1 in TMC, $r=-0.47$ for NFKB-c and SOCS1 in TCC and $\mathrm{r}=-0.47$ for NFKB-n and SOCS1 in TCC, respectively). Expression of TLR4 mRNA in TMC from the most aggressive zone of the neoplastic infiltration depending on the NFKB-c and NFKB-n immunostaining is shown in Fig. 3AB.

\section{The relationships of TLR4, IRAK1, TRAF6 and SOCS1 gene expression in border (TMC) and central (TCC) neoplastic tumor cells with clinicopathological parameters of the laryngeal carcinoma.}

To check whether TLR4-NFKB pathway molecules and SOCS1 gene expression analyzed in neoplastic border and central cells of the laryngeal tumor can potentially determine clinicomorphological features, the RT-PCR results were juxtaposed with the TFG total score and chosen parameters of TFG classification. The most numerous group of laryngeal carcinomas were advanced tumors (pT3 and pT4) characterized by G2 histological grade - 79.2\% (19/24). In 4.2\% (1/24) cases G1 and in $16.6 \%(4 / 24)$ cases G3 status were also confirmed. Diffuse growth of tumor infiltration and indistinct tumor front borderlines were most often seen in neoplasms group studied $-41.7 \%(10 / 24)$ and $41.7 \%$ (10/24), respectively. Less marked borderlines of tumor infiltration were characteristic for carcinomas in $16.6 \%(4 / 24)$ cases. In $8.3 \%(2 / 24)$ cases $10-13$ points, in $66.7 \%(16 / 24)$ cases $14-17$ points and in $25.0 \%(6 / 24)$ cases $18-21$ points of total TFG score in group studied were noted. Our study revealed a positive correlation between TRAF6 gene expression in TMC and histopathological differentiation $\mathrm{G}$ of the tumor $(\mathrm{r}=0.64, \mathrm{p}=0.006)$. Tumors characterized by a 

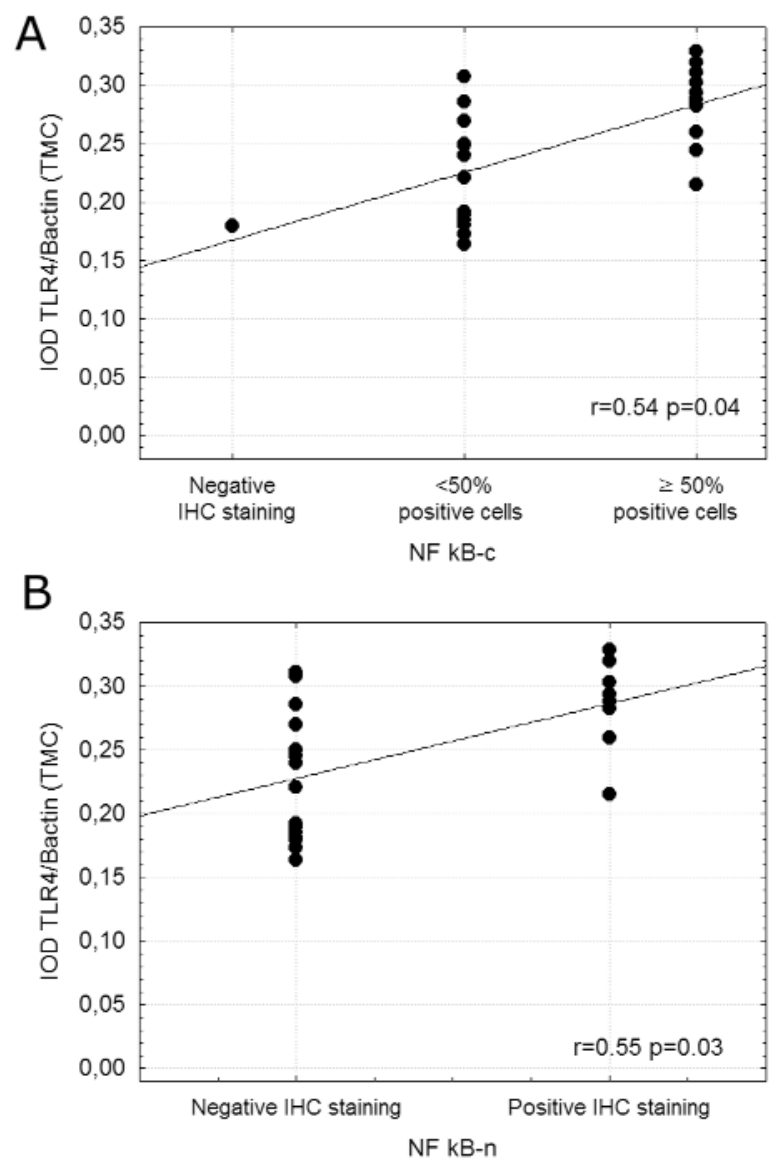

Fig. 3. (A) TLR4 mRNA expression in TMC from advanced tumors (pT3-pT4) depending on the NFKB-c IHC staining ( $\mathrm{r}=0.54$, $\mathrm{p}=0.04)$; (B) TLR4 mRNA expression in TMC from advanced tumors (pT3-pT4) depending on the NFKB-n IHC staining $(r=0.55$, $\mathrm{p}=0.03)$.

higher $\mathrm{G}$ status demonstrated a higher TRAF6 mRNA content. Our study also confirmed the presence of a significant relationship between TRAF6 expression in TMC and mode of tumor infiltration $(r=0.56, \mathrm{p}=0.02)$. A higher TRAF6 gene expression was associated with a diffuse mode of invasion with no distinct borderline. We also found that TRAF6 mRNA status in TMC had significant effect on TFG total score for advanced squamous cell laryngeal carcinomas (pT3-T4) $(\mathrm{r}=0.59$, $\mathrm{p}=0.01$ ). No relationships of statistical significance were recorded between TLR4, IRAK1, SOCS1 gene expression in TMC and other clinicomorphological parameters. However, we observed tends to increase of the malignant potential and aggressiveness of the tumor, estimated according to TFG total results with a low SOCS1 gene expression in TMC $(\mathrm{r}=-0.38)$, but this association did not reach a statistical significant level. Interestingly, in our study carcinomas characterized by a higher TLR4 mRNA content in border neoplasm cells manifested a lower $\mathrm{pT}$ stage $(\mathrm{r}=-0.37)$ and a less intensive depth of tumor invasion $(\mathrm{r}=-0.40)$.
Similarly, neoplasms with a higher SOCS1 mRNA level in TMC had a lower TFG total score $(r=-0.39)$. Our experiments have confirmed the presence of a significant relationship between TLR4 gene expression in TCC and TFG total score for advanced squamous cell laryngeal carcinoma ( $\mathrm{pT} 3-\mathrm{T} 4)(\mathrm{r}=0.69, \mathrm{p}=0.009)$. The group of patients with higher tumor front grading results exhibited higher TLR4 expression. We also found that SOCS1 mRNA content in TCC had significant effect on histological differentiation $\mathrm{G}(\mathrm{r}=-0.55$, $\mathrm{p}=0.04$ ). There, tumors with a low histopathological grade had a higher SOCS1 mRNA content. For neither IRAK1 nor TRAF6 there was a statistically significant association between mRNA expression levels in TCC and other clinicopathological features. However, we observed tends to increase proliferative and aggressive potential of laryngeal carcinomas with a high TRAF6 gene expression in TCC. Tumors with a higher TRAF6 mRNA content in central neoplasm cells were characterized by a higher status of tumor infiltration estimated according to the TFG classification $(\mathrm{r}=0.42)$. Expression of chosen molecules of TLR4-NFKB pathway and SOCS1 in TMC and TCC depending on the clinicopathological characteristics is shown in Figure $4 \mathrm{ABCD}$.

\section{The relationships of $N F \kappa B-c$ and $N F K B-n$ immunoexpression in laryngeal tumor tissues with clinicopathological parameters of the laryngeal carcinoma.}

To check whether $\mathrm{NF \kappa B}(\mathrm{p} 65)$ immunoexpression in tissues of squamous cell laryngeal carcinoma can determine clinicomorphologic tumor features, the IHC results of NFKB-c and NFKB-n were juxtaposed with the TFG total score and chosen parameters of the TFG classification. Our data demonstrated a significant correlation between NFKB-c and tumor front grading total results $(\mathrm{r}=0.30$ and $\mathrm{p}=0.04)$. The presence of immunostaining for $\mathrm{NFKB}(\mathrm{p} 65)$ in cytoplasm of the tumor tissue was connected with a higher an aggressive potential of the neoplasm determined by a higher cumulative TFG result. In addition we found that NFKB-c expression had significant effect on the mode of tumor invasion $(r=0.34, p=0.02)$. The presence of NFKB-c immunoexpression was associated with a diffuse mode of invasion characterized by no distinct borderline. Our results also indicated a significant differences in total TFG result and the mode of invasion between laryngeal tumors with negative (group 0 ) and positive (group 1 and 2) NFKB-c expression in tumor tissue ( $p=0.04$ for $T F G$ and $p=0.02$ for type of tumor infiltration, respectively). Moreover, we recorded a positive relationship between NFKB-n immunohistochemical staining in cellular nuclei and histopathological differentiation $\mathrm{G}$ of the tumor. This result reached 

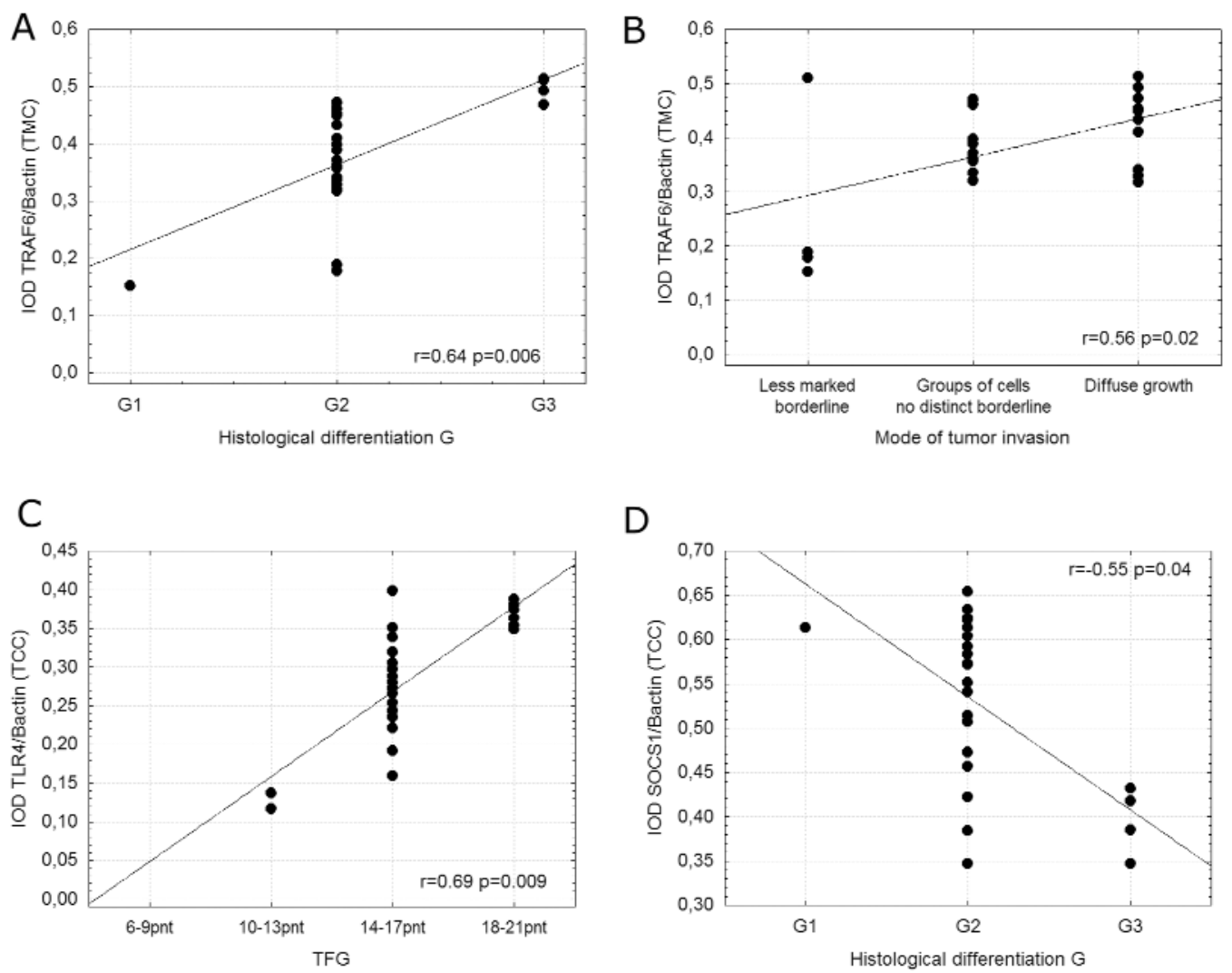

Figure 4. Expression of chosen molecules of TLR4-NFKB pathway and SOCS1 in TMC and TCC depending on the clinicopathological characteristics in advanced cases of laryngeal carcinoma (pT3-T4); (A) TRAF6 mRNA expression in TMC depending on the histological differentiation $\mathrm{G}(\mathrm{r}=0.64, \mathrm{p}=0.006)$; (B) TRAF6 mRNA expression in TMC depending on the mode of invasion of tumors ( $\mathrm{r}=0.56$, $\mathrm{p}=0.02)$; (C) TLR4 mRNA expression in TCC depending on the tumor front grading total score ( $r=0.69, p=0.09)$; (D) SOCS1 mRNA expression in TCC depending on the histological differentiation $\mathrm{G}(\mathrm{r}=-0.55, \mathrm{p}=0.04)$.

border-line statistical significance $(\mathrm{r}=0.28, \mathrm{p}=0.05)$. We noticed that tumors with a low morphological differentiation of the neoplasm front had a positive NFKB-n expression. Differences characterized various $G$ status with negative and positive IHC of NFKB-n also reached border-line statistical significance $(p=0.05)$. No relationships of statistical significance has been recorded of NFKB-c and NFKB-n immunoexpression in laryngeal tumor tissues with other clinicopathological parameters of the laryngeal carcinoma.

\section{Discussion}

SOCS1 protein has been shown to participate in lots of important regulatory mechanisms in immunocompetent cells and play the important role in many immunological and pathological processes $[1,4,6,9,12]$. In several reports SOCS/CIS protein family emerge as key physiological regulators of cytokine responses, including those that regulate the inflammatory responses by TLR and NFKB signals regulation $[1,4,6,15]$. What is important, recent reports introduce the function of SOCS/CIS protein family in the development and pro- gression of various types of malignancies. These results indicate a pivotal role of SOCS and accompanying pathway signaling molecules in the regulation of cellular growth and differentiation [1,9-11,16]. The potential molecular mechanism of SOCS1 is connected with inducing TLR4, IRAK1, TRAF6 and MAPK signaling suppression as well as the proteasomal degradation of p65 subunit of NFKB $[1,4,7,8,12]$. Interactions of SOCS protein with various other signaling molecules like JAKs/STAT1 pathway as well as FAK, IRS1/2 and vav are also introduced $[1,3,4,7,8$, 17-19]. The crosstalk among TLRs-NFKB pathways molecules and activation-dependent induction of effector cells were discussed in the literature, but these mechanisms remain unclear and it may cause divergent conclusions [3,4]. Our results confirm activity of SOCS1 and TLRs-NFKB signaling molecules genes in laryngeal neoplastic tissue. Our data are consistent with reports introducing TLRs utility to mediate the activation of NFKB and indirect regulation of the transcription process of the genes connected with apoptosis, cell cycle, proliferation, secretion of proinflammatory and angiogenic cytokines as well as growth fac- 
tors also in neoplasms $[1,20,21]$. Only single studies do not confirm role of TLRs in activity of NFKB pathway (22). SOCS proteins are introduced as tumor suppressors which overexpression is linked with decreasing in aggressive and metastatic potential due to inhibition of tumor cell proliferation [1,9-11,23].

In our study we did not confirmed relationship between SOCS1 mRNA content and NFKB activity in tumor tissue. These results are in agreement with data of other researchers that also suggest that SOCS proteins induced by TLR stimulation limit the extent of TLR signaling by inhibiting type I IFN signaling but not the main NFKB pathway $[4,24]$. These analyses of the early signaling pathway downstream of TLR4 demonstrated that SOCS1 had no regulatory effect on the activation or on the DNA binding capacity of NFkB. We found however in the literature, other data indicate the existence of mechanisms of the suppression of NFKB activity as a results of the indirect inhibition the INF $\beta-J A K-S T A T 1-N F K B$ signaling rapidly induced through the TRIF/IRF-3 (toll-interleukin-1 receptor domain-containing adapter inducing interferon-beta/IFN regulatory factor) after TLR4 stimulation and the direct degradation of NFKB p 65 by SOCS1 $[3,4]$. This is in line with the reports in which data indicate that SOCS1 is implicated in blocking TLRs signaling in immunocompetent cells activated by TLR agonists and negatively regulate not only the JAK/STAT pathway, but also the TLR-NFKB one $[4,25]$. Discrepancies in results reported on SOCS1 expression and on the relationship with NFKB may stem from different methods used in respective studies and the predominance of one of mentioned mechanisms.

Little is known on association of SOCS1 and TLRs-NFKB pathway molecules expression in tumor cells with clinicopathological characteristics of the primary laryngeal carcinoma. Our results point to the hypothesis that SOCS1 and TLRs-NFKB pathway molecules mRNA expression in tumor cells potentially determined tumor's behavior assessed according to TFG parameters and linked to deregulated cell growth, proliferation as well as aggressiveness of neoplastic infiltration in patients with laryngeal carcinoma. We observed that high TRAF6 mRNA content, the intermediary molecule of TLRs-NFKB pathway, in tumor's front neoplastic cells was a marker for more malignant phenotype assessed by G status and mode of invasion. Our research also showed that high expression of TLR4 in neoplastic border cells was associated with increased of tumor extensiveness estimated according to $\mathrm{pT}$ stage and mode of invasion. From a review of the literature we learned that TLR4 is also able to induce JAK1-STAT1 signaling pathway by TRIF/IRF-3 pathway and that STAT1 can function as a tumor suppressor $[1,26]$. These findings led us to conclusion that TLR4 stimulation effect in cancer cells is the results of a balance between the two signals: TLRs-NFKB pathway and JAK1-STAT1 pathway. Moreover, the mechanism of anti-tumor immunity via TLR4/MD2 complex stimulation is also described in the literature [27]. These findings suggest that the induction of apoptosis in human HNSCC cell lines is connected with p53independent pathway via TLR4 signaling. Interestingly, we noticed tends to increase the aggressiveness of the tumor according to TFG classification with low SOCS1 gene expression in border neoplastic cells. The similar relationships in tumor central cells were statistically significant. We also included that the more intensive immunostaining for NFKB in cytoplasm of the tumor front tissue the higher TFG total score was observed. Similarly to our observations, other reports also introduce evidence that SOCS/CIS family as well as TLR4-NFKB pathway molecules play the important role in determining tumor growth and progression of neoplasm disease and that SOCS1 act as antioncogenic protein [1,9,28-32]. Unfortunately, it is difficult to find in the literature reports directly binding SOCS/CIS family and TLRs activation with clinicopathological features of the tumor. Only in single publications the researchers suggest that mRNA expression level of SOCS and TLR4 genes and these proteins confer an invasive behavior and tumor progression to neoplastic cells $[9,33,34,35]$. The results of studies related to HNSCC cases frequently introduce the role of the TLR4 in modulation of MyD88 and IRAK4 expression as well as NFKB signaling and confirm their relationship with the tumor grade, proliferation and induction $\mathrm{NF \kappa B}$ translocation [35]. The other data show that activation of SOCS1 is an indicator for outcomes in patients with neoplastic disease and it can be connected with regulation of STAT1 by SOCS1 [9]. Our study is one of individual reports on the significance of SOCS1 and TLRs-NFKB pathway molecules mRNA content and the relationship with tumor front grading in carcinoma of the larynx.

We also introduce our voice in discussions on the importance of $\mathrm{NFKB}(\mathrm{p} 65)$ activity in determination of tumor's aggressive potential in laryngeal carcinoma. Our results show that NFKB immunoexpression in the carcinoma infiltration can be a marker of an invasive behavior of the neoplastic cells. This is in line with data of other reports introducing the important role of NFKB in the development of cancer [36-40]. In the literature, many researchers confirm a high transcription activity of NFKB in neoplastic cells and a high proportion with positive reaction in advanced tumors tissue (36-40). According to recent reports, the activation of $\mathrm{NF}-\kappa \mathrm{B}$ determined by the different methods used in respective studies, emerge as an independent prognostic marker connected with clinical and pathological characteristic of the various types of neoplasms [36-40]. 
Nevertheless, our study failed to demonstrate the relationship of mRNA content of chosen proteins in laryngeal neoplastic tissue with postoperative observation time. These results might be due to the fact that only $54 \%$ patients from studied group have been covered by the postoperative observation (other patients did not come forward in the research) and because seven patients in this group have reported on follow-up examination only once during one month after laryngectomy. However, we confirmed in our previous reports the existence of strong relationships between TFG results and overall survival in large group of patients with laryngeal squamous cell carcinoma [41]. Therefore, it allows us to conclude that the presence of significant relationships of TLR4-NFKB pathway molecules and SOCS1 gene expression with clinicomorphological features according to TFG, indirectly indicate that mRNA content of mentioned proteins could be prognostic predictors, although further studies are necessary.

Taken together our findings contribute to a better current understanding of the pathogenesis of squamous cell laryngeal carcinoma and the function of SOCS1 and TLR4-NFKB pathway molecules in this type of neoplasm. Furthermore, if confirmed in larger studies, determination of these proteins expressions could be used as biomarkers for tumor proliferation and aggressiveness. These findings could be helpful for clinicians in the assessment and counseling of patients affected by these cancers or for scientists to consider new potential therapeutic targets for the treatment of these tumors.

Acknowledgment: This work was supported by grant from the National Science Council, Poland (KBN N403 04332/2326) and research grant from the Medical University of Lodz, Poland (UM 502-12-471).

\section{References}

[1] Yoshimura A, Nishinakamura H, Matsumura Y, Hanada T. Negative regulation of cytokine signaling and immune responses by SOCS proteins. Arthritis Res Ther. 2005; 7(3):100-110

[2] Alexander WS, Hilton DJ. The role of suppressors of cytokine signaling (SOCS) proteins in regulation of the immune response. Annu Rev Immunol. 2004; 22:503-529.

[3] Gingras S, Parganas E, de Pauw A, Ihle JN, Murray PJ. Reexamination of the role of suppressor of cytokine signaling 1 (SOCS1) in the regulation of toll-like receptor signaling. $J$ Biol Chem. 2004;279(52):54702-54707.

[4] Baetz A, Frey M, Heeg K, Dalpke AH. Suppressor of cytokine signaling (SOCS) proteins indirectly regulate tolllike receptor signaling in innate immune cells. $J$ Biol Chem. 2004;279(52):54708-54715.

[ 5] Kimura A, Naka T, Muta T, Takeuchi O, Akira S, Kawase I et al. Suppressor of cytokine signaling-1 selectively inhibits LPS-induced IL-6 production by regulating JAK-STAT. Proc Natl Acad Sci USA. 2005;102(47):17089-17094.

[6] Yoshimura A, Ohishi HM, Aki D, Hanada T. Regulation of TLR signaling and inflammation by SOCS family proteins. $J$ Leukoc Biol. 2004; 75(3):422-427.
[7] Mansell A, Smith R, Doyle SL, Gray P, Fenner JE, Crack PJ et al. Suppressor of cytokine signaling 1 negatively regulates Toll-like receptor signaling by mediating Mal degradation. Nat Immunol. 2006; 7(2):148-155.

[8] Mansell A, Brint E, Gould JA, O'Neill LA, Hertzog PJ. Mal interacts with tumor necrosis factor receptor-associated factor (TRAF)-6 to mediate NF-kappaB activation by toll-like receptor (TLR)-2 and TLR4. J Biol Chem. 2004;279(36): 37227-37230.

[9] Haffner MC, Petridou B, Peyrat JP, Révillion F, Müller-Holzner E, Daxenbichler $\mathrm{G}$ et al. Favorable prognostic value of SOCS2 and IGF-I in breast cancer. BMC Cancer. 2007; 7:136.

[10] Weber A, Hengge UR, Bardenheuer W, Tischoff I, Sommerer F, Markwarth A et al. SOCS-3 is frequently methylated in head and neck squamous cell carcinoma and its precursor lesions and causes growth inhibition. Oncogene. 2005; 24(44):66996708.

[11] Rottapel R, Ilangumaran S, Neale C, La Rose J, Ho JM, Nguyen MH et al. The tumor suppressor activity of SOCS-1. Oncogene. 2002; 21(28):4351-4362.

[12] Hertzog PJ, O'Neill LA, Hamilton JA. The interferon in TLR signaling: more than just antiviral. Trends Immunol. 2003; 24(10):534-539.

[13] John Wiley \& Sons. TNM Classification of Malignant Tumours. 6th edition Hoboken: New Jersey; 2002.

[14] Welkoborsky HJ, Hinni M, Dienes HP, Mann WJ. Predicting reccurence and survival in patients with laryngeal cancer by means of DNA cytometry, tumor front grading and proliferation markers. Ann Otol Rhinol Laryngol 1995; 104: 503-511.

[15] Yoshimura A. Negative regulation of cytokine signaling. Clin Rev Allergy Immunol. 2005; 28(3):205-20.

[16] Evans MK, Yu CR, Lohani A, Mahdi RM, Liu X, Trzeciak AR et al. Expression of SOCS1 and SOCS3 genes is differentially regulated in breast cancer cells in response to proinflammatory cytokine and growth factor signals. Oncogene. 2007; 26(13):1941-1948.

[17] Lebrun P, Van Obberghen E. SOCS proteins causing trouble in insulin action. Acta Physiol (Oxf). 2008; 192(1):29-36.

[18] Liu E, Côté JF, Vuori K. Negative regulation of FAK signaling by SOCS proteins. EMBO J. 2003; 22(19):50365046.

[19] De Sepulveda P, Ilangumaran S, Rottapel R. Suppressor of cytokine signaling-1 inhibits VAV function through protein degradation. J Biol Chem. 2000; 275(19):14005-14008.

[20] Khvalevsky E, Rivkin L, Rachmilewitz J, Galun E, Giladi H. TLR3 signaling in a hepatoma cell line is skewed towards apoptosis. J Cell Biochem. 2007; 100(5):1301-1312.

[21] Kawai T, Akira S. Signaling to NF-kappaB by Toll-like receptors. Trends Mol Med. 2007; 13(11):460-469.

[22] Fraczek J, Kim TW, Xiao H, Yao J, Wen Q, Li Y et al. The kinase activity of IL-1 receptor-associated kinase 4 is required for interleukin-1 receptor/toll-like receptor-induced TAK1-dependent NFkappaB activation. J Biol Chem. 2008; 283(46):31697-31705.

[23] Sutherland KD, Lindeman GJ, Choong DY, Wittlin S, Brentzell L, Phillips W et al. Differential hypermethylation of SOCS genes in ovarian and breast carcinomas. Oncogene. 2004; 23(46):7726-7733.

[24] Prele CM, Woodward EA, Bisley J, Keith-Magee A, Nicholson SE, Hart PH. SOCS1 regulates the IFN but not NFkappaB pathway in TLR-stimulated human monocytes and macrophages. J Immunol. 2008; 181(11):8018-8026.

[25] Gingras S, Parganas E, de Pauw A, Ihle JN, Murray PJ. Reexamination of the role of suppressor of cytokine signaling 1 (SOCS1) in the regulation of toll-like receptor signaling. J Biol Chem. 2004; 279(52):54702-54707.

[26] Dyer KF, Kimak M, Zhang Q, Gooding WE, Chaillet JR, Chai RL, Ferrell RE et al. Decreased STAT1 expression by pro- 
moter methylation in squamous cell carcinogenesis. $J$ Natl Cancer Inst. 2006; 98(3):181-189.

[27] Okamoto M, Oshikawa T, Tano T, Ohe G, Furuichi S, Nishikawa $\mathrm{H}$ et al. Involvement of Toll-like receptor 4 signaling in interferon-gamma production and antitumor effect by streptococcal agent OK-432. J Natl Cancer Inst. 2003; 95(4):316-326.

[28] Szczepanski M, Stelmachowska M, Stryczynski L, Golusinski W, Samara H, Mozer-Lisewska I et al. Assessment of expression of toll-like receptors 2, 3 and 4 in laryngeal carcinoma. Eur Arch Otorhinolaryngol. 2007; 264:525-530.

[29] Squarize CH, Castilho RM, Sriuranpong V, Pinto DS Jr, Gutkind JS. Molecular cross-talk between the NFkappaB and STAT3 signaling pathways in head and neck squamous cell carcinoma. Neoplasia. 2006; 8:733-746.

[30] Huang B, Zhao J, Shen S, Li H, He KL, Shen GX et al. Listeria monocytogenes promotes tumor growth via tumor cell toll-like receptor 2 signaling. Cancer Res. 2007; 67:43464352.

[31] Frenzel H, Hoffmann B, Brocks C, Schlenke P, Pries R, Wollenberg B. Toll-like receptor interference in myeloid dendritic cells through head and neck cancer. Anticancer Res. 2006; 26:4409-4413.

[32] Stary G, Bangert C, Tauber M, Strohal R, Kopp T, Stingl G. Tumoricidal activity of TLR7/8-activated inflammatory dendritic cells. J Exp Med. 2007; 2004:1441-1451.

[33] Simiantonaki N, Kurzik-Dumke U, Karyofylli G, Jayasinghe C, Michel-Schmidt R, Kirkpatrick CJ. Reduced expression of TLR4 is associated with the metastatic status of human colorectal cancer. Int J Mol Med. 2007; 20(1):21-29.

[34] Ohara T, Morishita T, Suzuki H, Hibi T. Heterozygous Thr 135 Ala polymorphism at leucine-rich repeat (LRR) in genomic DNA of toll-like receptor 4 in patients with poorlydifferentiated gastric adenocarcinomas. Int J Mol Med. 2006; 18(1):59-63.

[35] Szczepanski MJ, Czystowska M, Szajnik M, Harasymczuk M, Boyiadzis M, Kruk-Zagajewska A et al. Triggering of Toll-like receptor 4 expressed on human head and neck squamous cell carcinoma promotes tumor development and protects the tumor from immune attack. Cancer Res. 2009; 69(7):3105-13

[36] Escárcega RO, Fuentes-Alexandro S, García-Carrasco M, Gatica A, Zamora A. The transcription factor nuclear factorkappa B and cancer. Clin Oncol. 2007; 19(2):154-161.

[37] Sun XF, Zhang H. NFKB and NFKBI polymorphisms in relation to susceptibility of tumour and other diseases. Histol Histopathol. 2007; 22(12):1387-1398.

[38] Lerebours F, Vacher S, Andrieu C, Espie M, Marty M, Lidereau $\mathrm{R}$ et al. NF-kappa B genes have a major role in inflammatory breast cancer. BMC Cancer. 2008; 8:41.

[39] Jin X, Wang Z, Qiu L, Zhang D, Guo Z, Gao Z et al. Potential biomarkers involving IKK/RelA signal in early stage nonsmall cell lung cancer. Cancer Sci. 2008; 99(3):582-589.

[40] Kourelis K, Sotiropoulou-Bonikou G, Vandoros G, Repanti M, Varakis I, Goumas P. Coordinated upregulation of COX-2 and NF-kappaB is a steady feature of laryngeal carcinogenesis. ORL J Otorhinolaryngol Relat Spec. 2007;69(3):181-9.

[41] Starska K, Kulig A, Lukomski M. Tumor front grading in prediction of survival and lymph node metastases in patients with laryngeal carcinoma. Adv Med Sci. 2006; 51:200-204.

Submitted: 21 April, 2009 Accepted: 26 July, 2009 